Revista Brasileira de Meteorologia, v.26, n.4, 515 - 528, 2011

\title{
RANDOMIZED CONVECTIVE CLOUD SEEDING EXPERIMENT IN EXTENDED AREAS IN CUBA (EXPAREX)
}

\author{
DANIEL MARTINEZ-CASTRO ${ }^{1}$, CARLOS A PÉREZ-SANCHEZ ${ }^{1}$, BORIS P KOLOSKOV ${ }^{2}$, VICTOR V. \\ KORNEEV $^{2}$, VICTOR V PETROV ${ }^{2}$, MIKAHAIL STRUININ ${ }^{3}$, FELIX GAMBOA-ROMERO ${ }^{1}$, SADIEL \\ NOVO-CUERVO ${ }^{1}$
}

\author{
${ }^{1}$ Instituto de Meteorología de Cuba, Havana, Cuba; \\ ${ }^{2}$ Agency of Atmospheric Technologies of Russian, Russian; \\ ${ }^{3}$ Central Aerological Observatory of Russian, Russian
}

daniel.martinez@insmet.cu, carlosa_perez_sanchez@yahoo.com,bkoloskov@yahoo.com, attech@attech.ru, vpetrov777@yahoo.com,strunin@online.ru, felixgamboaromero@yahoo.com, sadielnovo@gmail.com

Received January 2010 - Accepted March 2011

\begin{abstract}
The Randomized Convective Cloud Seeding Experiment in Extended Areas (EXPerimento aleatorizado de siembra de nubes en AReas EXtensas, EXPAREX) is being implemented in Camagüey, Cuba and adjacent regions from August 2005 as the continuation of a previous successful experiment (PCMAT), held in the period 1982-1990. The first season of the experiment was exploratory and was focused on upgrading facilities, equipment and software, including an An-26 instrumented aircraft and the 10-cm MRL-5 weather radar. It was aimed at implementing methodologies and testing the application of the experimental design, excluding the randomization scheme, which was scheduled to be started in the second experimental year, in the rainy season of 2006. The field operations of the confirmatory phase started only in October, 2006, when seven experimental units, treated under a randomized scheme, were qualified. In the 2007 experiment, 13 more experimental units were processed. The general description, experimental design, procedures and characterization of the first two experimental seasons of the confirmatory phase of EXPAREX are presented in this work. Is it shown that the experimental clouds processed in the first two seasons of the experiment have similar characteristics to the PCMAT clouds, so that the conclusions of previous physical research are applicable. Key words: cloud seeding, precipitation enhancement, cloud physics, convective clouds

RESUMO: EXPERIMENTO ALEATÓRIO DE SEMEADURA DE NUVENS CONVECTIVAS EM ÁREAS EXTENSAS EM CUBA (EXPAREX).

O Experimento Aleatório de Semeadura de Nuvens Convectivas em áreas extensas (EXPAREX) vem sendo realizado em Camagüey, Cuba e em regiões adjacentes, desde agosto de 2005, como continuação de experiência anterior bem sucedida (PCMAT) realizada entre 1982 e 1990. A primeira temporada do experimento foi exploratória e concentrou-se na modernização das instalações, equipamentos e software, incluindo um avião An-26 instrumentado e um radar meteorológico MRL-5, de comprimento de onda de 10 centímetros. Nesta fase destinou-se a aplicar e testar metodologias, além de definir o desenho experimental, com exclusão do regime de aleatoriedade, que estava programado para ser iniciado no segundo ano, na estação chuvosa de 2006. As operações de campo da fase de confirmação apenas se iniciaram em outubro de 2006, quando sete unidades experimentais, tratadas sob um regime aleatório, foram qualificadas. No experimento de 2007, mais 13 unidades experimentais foram processadas. A descrição geral, delineamento experimental, procedimentos e caracterização das duas primeiras estações experimentais da fase de confirmação de EXPAREX são apresentados neste trabalho. É mostrado que as nuvens experimentais tratadas têm características semelhantes às nuvens do PCMAT, indicando que as conclusões da investigação física obtidas anteriormente são aplicáveis. Palavras-chave: semeadura de nuvens, aumento da precipitação, física de nuvens, nuvens convectivas.
\end{abstract}




\section{INTRODUCTION}

The problem of investigating and proving the possibility of obtaining additional rainfall by seeding clouds with different types of reagents has been a focus in cloud physics research for the last more than 50 years.

The discovery of the possibility to freeze considerable amounts of supercooled water by using cooling agents like dry ice or artificial ice nuclei, like silver iodide aerosol can be considered as the first step in this saga of experimental and theoretical research. In spite of the fact that from the late 40 s up to the present, many operational and research cloud seeding projects have taken place in different parts of the world, the problem of the feasibility of rainfall enhancement by cloud seeding is still considered as unsolved (Levin, 2009; WMO, 2010).

One of the first relevant experiments was carried out in Israel in three stages, known as Israel I, II and III. Under the static seeding hypothesis (Silverman, 1986), this experiment of rain enhancement by silver iodide seeding was carried out between the 60 s and the 70 s and obtained statistically significantly positive increase of rain gauge-measured rainfall in extended fixed areas. (Gagin and Neuman, 1981). The reagent was dispersed into the clouds from cloud base by an aircraft along windward flight lines. This approach was complemented by the introduction of additional silver iodide nuclei from ground based burners.

Other relevant early experiments, carried out in the 70s, were the Florida Area Cumulus Experiments I y II (FACE), (Woodley et al., 1982, Bramston et al., 1983) which objective was to prove the dynamic seeding hypothesis, enunciated and studied by Simpson et al (1967) some years before. This early work allowed to understand the basic physical principles of this hypothesis and to formulate it as a conceptual model. The FACE experiment also served as a paradigm for the scheme to be followed in this kind of effort, including cloud physics studies, precipitation measurement techniques, combining radar and raingauges, the definition of experimental units and data processing procedures.

The South West Texas experiments, which tested silver iodide seeding of the tops of convective clouds under the dynamic seeding hypothesis showed a small average increase in cloud top height for seeded clouds, and much larger increases in cloud area and lifetime and in precipitation volume. As a result of these experiments, a new conceptual model of dynamic seeding of convective clouds was presented (Rosenfeld and Woodley, 1993), showing that the additional energy released by dynamic cloud seeding not necessarily produces great increase in cloud top height, but part of the energy may be used for creating downdrafts producing low level convergence which boosts the formation of daughter cells and the horizontal expansion of the seeded cloud.
In 1994-1998, randomized cloud seeding experiments was carried out in Thailand, aimed at testing the new concept of dynamic cloud seeding. Even if these experiments did not reach a statistically significant result, and so, were not considered as conclusive, for not having attained the amount of experimental units required by design, they had a high methodological and scientific value and positive results (Rosenfeld et al., 1999).

In 1979, The Cuban Project for Artificial Weather Modification (PCMAT, Proyecto Cubano de Modificación Artificial del Tiempo, Koloskov et al., 1996) was undertaken by the Cuban Institute of Meteorology in collaboration with the Central Aerological Observatory (CAO) of Russia. During the earliest stages of the Project, the efforts were devoted to selecting an appropriate site and season (1979-1981), for preliminary assessment of the physical characteristics of Cuban clouds (Pérez et al., 1994; Martínez, 1999; Martínez and Gori, 1999; Petrov et al., 2004) and their suitability for glaciogenic cloud seeding. An exploratory experiment was conducted in the period from 1982 to1985, based on the new dynamic seeding concept for convective cloud seeding, as well as the Thailand and South West Texas experiments.

The confirmatory phase of this experiment was based on randomized seeding of individual convective clouds and cloud systems and was conducted in the Camagüey Experimental Area (CEA), Cuba, during the six years from 1985 through 1990. The response of tropical convective clouds to cold-cloud seeding with silver iodide pyrotechnics in terms of their morphological, microphysical, and dynamical properties were evaluated. In this phase of the experiment, a total of 46 individual convective clouds, 24 seeded and 22 no-seeded, and 82 cluster cells, 42 seeded and 40 not-seeded, were studied. The results of analysis of three-dimensional radar data have shown that the seeding of growing clouds with top temperatures between $-10^{\circ} \mathrm{C}$ to $-20^{\circ} \mathrm{C}$ increases their lifetime, maximum height, area and rain volume by $120 \%$ for individual clouds and $65 \%$ for cloud clusters, as compared to unseeded ones, at better than $5 \%$ level of significance (Koloskov et al., 1996).

Considering the problem of shortage of fresh water on the eastern part of Cuba, which was severe in 2004 and in the beginning of 2005, the Cuban Government decided to support the resumption of the experiments in the CEA. With this purpose, the Camagüey Meteorological Center was equipped with a new GPS-based rawinsond station, the MRL-5 radar was digitized and automated and a network of digital pluviometers was installed. The Randomized Convective Cold Cloud Seeding Experiment in Extended Areas (EXPerimento aleatorizado de siembra de nubes en AReas EXtensas, EXPAREX) is being implemented in Camagüey and adjacent regions from August 2005 as the continuation of PCMAT. 
The first season of the experiment was focused on upgrading facilities, equipment and software, including an An-26 instrumented aircraft and the 10-cm MRL-5 weather radar. This stage of the experiment was aimed at implementing methodologies and testing the application of the experimental design, excluding the application of the randomization scheme, which was scheduled to be started in the second experimental season, corresponding to the rainy season of 2006. As a result of delays in implementation of the experiment in the second season, the field operations of the confirmatory phase of the experiment started only in October, 2006. Seven experimental units were qualified under the program of the randomized seeding experiment. The 2007 experiment was made in September-October and 13 experimental units were processed. The general description, experimental design, procedures and characterization of the first two experimental seasons of the confirmatory phase of EXPAREX are presented in this work.

\section{EXPERIMENTAL DESIGN}

\subsection{Seeding hypothesis}

The dynamic seeding concept applies to mixed phase convective clouds. It is based the artificial conversion of supercooled water to ice in a short term releasing a significant amount conversion of freezing latent heat, which heats the cloud (Rogers and Yau, 1989).

For isobaric freezing, the increase in temperature can be nearly $0.3^{\circ} \mathrm{C}$ for every $\mathrm{g} / \mathrm{kg}$ of supercooled water, frozen at $-10^{\circ} \mathrm{C}$. An additional increase in temperature, similar in magnitude, is produced by the deposition of water vapor on the crystals, occurring as soon as the crystals are formed. Generally, not all the water glaciates, but other processes, like accretion of supercooled droplets in the crystal, known as riming, can contribute with additional heat release, and so, partially compensate the deficit introduced by non complete freezing. This resulting additional heating adds up to the buoyancy of the updraft. The estimations of Pérez et al. (1992; 2008), based in the measurements of temperature excess and phase composition show that this is consistent with the behavior of experimental clouds in PCMAT.

The experiment is based on the revised dynamic seeding conceptual model described by Rosenfeld and Woodley (1993), which involves a series of events beginning initially on the scale of individual treated clouds or cells and cascading to the scale of the experimental unit, covering an area of nearly $2000 \mathrm{~km}^{2}$. The massive seeding is hypothesized to produce rapid glaciation of the supercooled cloud water (SCW) in the updraft regions. This fast conversion of cloud water into ice enhances the release of latent heat, increases cloud buoyancy, invigorates the updraft, and acts to spur additional cloud growth.
The revised dynamic seeding concept can be summarized as a hypothesized simplified chain of events, as follows:

a) Massive seeding of the supercooled region of the updraft freezes most of the water in this region.

b) Latent heat is released by the freezing process, increasing buoyancy in the seeded volume. This process acts very fast in tropical clouds because of the presence of raindrops which formed by a natural active collision-coalescence process. These frozen drops continue growing as graupel, fed by riming of the supercooled droplets. The frozen graupel particles have less density than drops of the same mass, and a greater collection coefficient for supercooled drops.

c) The combined effect of increase in buoyancy and decrease in precipitation particle density, compared with natural cloud development, compensates the increase in weight of the precipitation particles, allowing them to remain in the updraft, in the upper part of the cloud, for more time, delaying the destruction of the updraft and, consequently, increasing cloud lifetime.

d) Eventually, precipitation stored in the upper region of the cloud descends. If weak or moderate wind shear is present, an adjacent downdraft is formed, so that the updraft unloads itself to the downdraft, keeping its buoyancy for a long time.

e) The downdraft produces local convergence at low levels, inducing the formation of daughter cells, some of which can produce additional precipitation.

f) If this new cells become suitable for seeding, a multiplier effect can be achieved, so that, if dynamical conditions are favorable, a long-duration system can be sustained by successive seeding of new cells.

The actual occurrence of each of the steps of this conceptual model depends on the existence of suitable environmental conditions for cloud seeding. In general, three types of situations may exist: in the first, environmental conditions propitiate the natural formation and development of very deep convection systems producing much precipitation even without cloud seeding. This takes place under the synoptic influence of low pressure centers, intense easterly waves etc. The second is when the conditions are unfavorable for convective development, so that no suitable for seeding cloud will form on the area. The third situation is when there are conditions for deep convection, but they are not extreme, so that cumuli can reach levels with significant supercooled layer in their top regions, but they do not develop spontaneously to long lasting mesoscale convective systems. Only in this situation, the above explained conceptual model applies fully, so that the additional energy transferred to the system by seeding can radically modify its behavior

In intermediate cases, it is possible that some of the steps of the chain of events apply, but not the rest, so that the precipitation increase potential still exists, but would be limited. 


\subsection{EXPERIMENTAL AREA}

Experimental units (Pérez et al., 2005) will be selected from the area of a $150 \mathrm{~km}$ circle with its center in the Camagüey radar, which coordinates are: $77^{\circ}, 48^{\prime}, 03^{\prime \prime} \mathrm{W}$ y $21^{\circ}, 26^{\prime}, 15^{\prime \prime} \mathrm{N}$ (Figure 1), excluding the regions over the sea and the area of a circle of $20 \mathrm{~km}$, centered in the radar, called the "dead zone", which is too near from the radar to obtain full 3-dimensional arrays of radar reflectivity data for deep convective clouds.

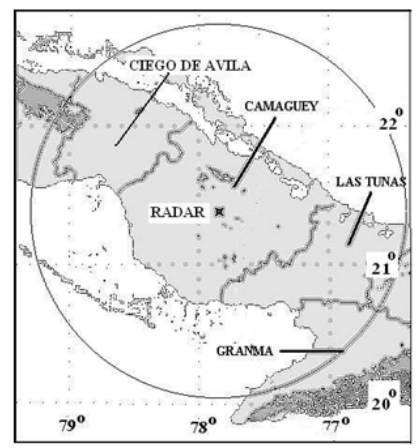

Figure 1 - Experimental area.

\subsection{Experimental units}

\subsubsection{Definition and selection criteria}

To minimize the duration of the experiment, and to obtain, at the same time, an evaluation of the possibility to influence rainfall totals in areas of local economic impact which are capable of being continuously seeded by an aircraft, a floating target scheme was designed, with experimental unit area of nearly $2000 \mathrm{~km}^{2}$

The characteristics defining the experimental units and used as selection criteria are the following:

a) An experimental unit in EXPAREX consists of a group of convective clouds or cloud systems which towers receive real seeding (introduction of AgI aerosol) or simulated (without introduction of AgI aerosol) treatment within a radius of $25 \mathrm{~km}$, centered in the convective cell which received the first treatment. The area of such an experimental unit is nearly 2000 $\mathrm{km}^{2}$, which is estimated as roughly the greatest area that can be effectively treated by an An-26 aircraft. The selection criteria of the experimental units are based on the same principles applied in the confirmatory experiment of PCMAT for the cloud, including additional environmental criteria.

b) The towers of the cloud systems selected for treatment must have, at flight altitude, liquid water content (LWC) greater than $0.5 \mathrm{~g} / \mathrm{m}^{3}$, sustained for more than a second (aircraft velocity at treatment level is nearly $100-120 \mathrm{~m} / \mathrm{s}$ ), and the updraft vertical velocity $\mathrm{W}$ must be greater than $5 \mathrm{~m} / \mathrm{s}$, sustained in the same period; the tower horizontal characteristic dimension ('diameter') must be greater than $2 \mathrm{~km}$, and it must have the general appearance of a young, developing tower (high optical density, cauliflower aspect in the top, no sign of dissipation or glaciation in the top). Statistics on liquid water content and updraft velocity obtained in PCMAT for similar cloud systems show that the above mentioned measurable requirements are generally met by Cuban developing clouds in the experimental area and season, so that a preliminary decision in situ measurement was not requested by the experimental design in EXPAREX in order to avoid the possibility of loosing the right time window for seeding, which can be very narrow in tropical conditions. The fulfillment of the LWC and W requirements is tested in every treatment, and particularly in the first treated cloud of each experimental unit, can be taken into account in the preliminary analysis of the database before unveiling the treatment sequence.

c) No cloud in the experimental unit may have top height greater than $10 \mathrm{~km}$.

d) Cloud top heights of the treated towers must be in the range 6-8 km, corresponding to a temperature range of -7 to -20 ${ }^{\circ} \mathrm{C}$ (Martínez et al., 2002).

e) At the time of the selection of the first treatment of an experimental unit, its coordinates, which define the center of the unit, must be at more that $40 \mathrm{~km}$ from any cumulonimbus having radar reflectivity of $50 \mathrm{dBZ}$ or greater.

The treatment of new towers in an experimental unit will finish when al least one of the following conditions holds:

a) More than an hour has elapsed since the last treatment and the radar echoes inside the $25 \mathrm{~km}$ radius of the unit do not have conditions for treatment.

b) The experimental unit moves further than $150 \mathrm{~km}$ from the radar.

c) The radar has a technical problem

d) The aircraft has a technical problem or gets near to the security flight time range

\subsubsection{Obtaining information from the experimental units}

The main surveillance of the evolution of experimental units an all the cloud and precipitation field in the experimental area is performed using the radar reflectivity field of the MRL-5 weather radar operating 24 hours a day in either the surveillance or volume-scan modes, recording the three-dimensional structure of clouds and precipitation over experimental territory every 5 minutes.

This information is recorded since the moment of appearance of the first radar echo in the area, until no echo is present. Radar data are sequentially processed by 
different software packages until detailed characteristics of he experimental units are obtained. The displacement through the experimental area of the formerly defined experimental units are identified and followed during all their life time by an objective algorithm which has been implemented in an interactive software system.

Microphysical and dynamic variables in the cloud towers are measured in situ by the aircraft, which is equipped with measuring instruments to monitor the liquid water content, phase composition, precipitation particle size distribution in the clouds and temperature fluctuations and vertical and horizontal velocity fluctuations inside and outside the clouds. Aircraft information, including physical and navigation parameters is managed by a data acquisition system (DAS) which allows real time data processing and post-processing, including flight track and graphical output of cloud parameters. DAS output is transmitted in real time to the Flight Control Group, in the Experiment Direction Center.

For every experimental day, all meteorological information and analysis which is considered as relevant to the description of the environment is gathered, including upper air soundings, satellite imagery, general and special diagnosis and forecasts and model output. Every day, a three domains configuration of the MM5-V3 model is run, with resolution of $9 \mathrm{~km}$ over Cuba, taking boundary conditions from NOAA GFS global model output, providing forecast of the evolution of the main meteorological variables in the experimental area for the next three days.

\subsection{Randomization}

The treatment decision is to be randomized on a unitby-unit basis and selected convective clouds within the unit shall be treated with AgI in the case when the "seed" decision is made or shall be penetrated without seeding in the case of a "no-seed" decision. The treatment decision is to be drawn inside the seeding aircraft before the treatment pass, and the PV-26 pyrotechnic flares are ejected into the clouds every 1-2 seconds. About 10-25 flares are to be ejected on each pass when the decision is "seed" (S). Seeding is simulated in the case "no-seed" (NS) decision. There is no tag in the records to identify seeded from non seeded cases, so that this information is kept in sealed envelopes which are managed by the seeding operator who does not take part in data processing.

\subsection{Experimental procedure.}

\subsubsection{Preliminary declaration of experimental day}

The first step of the experimental procedure is the daily morning briefing, which takes place at 10:00 LST to discuss the preliminary experimental day declaration. As a result of the discussions, the head of the project makes the preliminary experimental day declaration. If the day is declared as "experimental", the time for which the aircraft should be ready to take off is established. As a rule, take off is fixed for 13:00-15:00 LST. Just before that time, an update is made of the available meteorological information and mainly of the radar picture, to decide the immediate take off or to wait at the airport until the first perspective convective echoes appear. The leading scientist of the aircraft team keeps in constant telephone contact with the leading scientist of the ground team to decide the actual take off time.

\subsubsection{Flight and treatment procedures}

If the decision to take off is eventually taken, the aircraft will ascend, heading to the region recommended by the radar meteorologist. The flight level is at the $-7^{\circ} \mathrm{C}$ isotherm $(5700-$ 6000) $\mathrm{m}$. Experimental units are selected jointly by the aircraft and ground team leaders, though the final decision corresponds to the aircraft. As soon as an experimental unit is selected, the envelope enclosing the randomized treatment decision is open by the seeding operator without any notice to any other member of the staff. The operator proceeds consequently for the rest of the clouds in the experimental unit, and the envelope is closed again after finishing working on it. In any case, the leading scientist gives the instructions to seed in the appropriate moment, but if randomized decision is "no seed", he disconnects the launcher system and presses the buttons simulating seeding, so that the rest of the staff can't notice the type of treatment actually applied. The experimental unit is being treated with subsequent penetrations of different cloud towers which are considered as apt for seeding. In each penetration, the flight should be horizontal and straight, including the segments before and after the cloud and the pilot should try to hold the air velocity as constant as possible. Measurement of cloud and environmental parameters are made for each treated tower. This procedure continues until one hour after no suitable cloud for seeding is left in the area or any other problem prevents continuing the flight. In the case that no suitable cloud is found, and hence, no experimental unit is declared, the day is eventually declared as non-experimental. Figure 2 shows the experimental procedure as a simplified flow chart.

During all the flight time, the radar continues scanning the experimental area in 5 minute cycles, en even after the landing of the aircraft(s), until no echo is present in the area.

The silver iodide flares are introduced directly in the updraft of the clouds by releasing one flare every 1 or 2 seconds, so as to propitiate the dispersion of the glaciogenic aerosol in the cloud in the layer between the -4 and $-10 \mathrm{oC}$, 


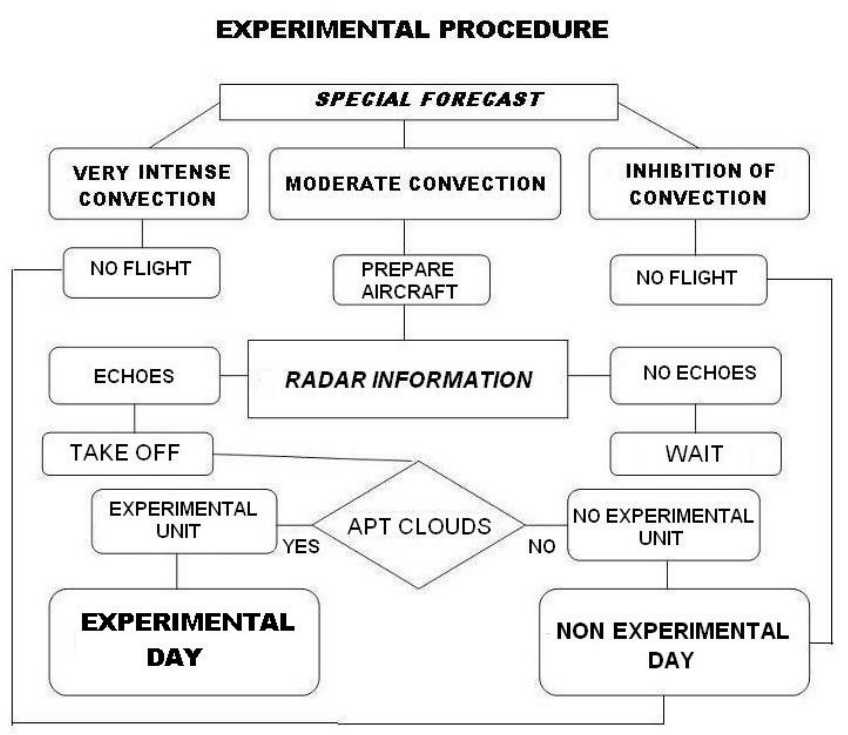

Figure 2 - Scheme of the daily experimental procedure.

with a concentration of about 100 nuclei per liter of cloudy air. Crystallization of about $50-60 \%$ of the supercooled water in this region is hypothesized. Using the values of the turbulence coefficient obtained by Martínez (1999), it can be estimated that the dispersion of the reagent behaves similarly as reported in FACE (Woodley and Sax, 1976), so that the active reagent is enough for dynamic seeding (Cotton, $1972 \mathrm{a}, \mathrm{b}$ ).

\subsection{Glaciogenic reagent}

he glaciogenic reagent applied in the experiment is the pyrotechnic mixture of the Russian flares PV-26. This mixture has an output of $1.7 \times 10^{14}$ glaciogenic nuclei per gram at -10 ${ }^{\circ} \mathrm{C}$ and $7.0 \times 10^{13}$ at $-6{ }^{\circ} \mathrm{C}$. The flares burn during 40 s and have a descending burning track of $1.5-2 \mathrm{~km}$ in moderate updraft.

\subsection{Projected duration of the experiment}

The success criteria for the experiment are the increase in precipitation from the seeded cells and for the experimental units containing these cells, in both cases with statistical significance and physical plausibility and consistence. According with the results of previous experiments, success must be sought, in first place from the sample of seeded cells, which received the reagent directly. The increase in precipitation in the experimental unit is expected to be a consequence of the increase in its constituent seeded cells, but this has to be proved independently, to show that the effect in the floating areas is significant.

Gabriel's (1999) formulation, using simple and double ratios in the statistical evaluation of artificial rain enhancement experiments, constitutes the base for the calculation of the number of experimental units that is needed for a given significance level. The size of the sample if obtained from:

$$
N=\left(Z_{\alpha}+Z_{\beta}\right)^{2} x\left(\sigma^{2} / \delta^{2}\right)
$$

here, $Z_{\alpha}$ is the cumulative fraction $(1-\alpha)$ of a standard normal distribution; $Z_{\beta}$ is its percentile $(1-\beta) ; \alpha$ is the significance level for a one-tail test; $(\alpha=0.05) ; \beta$ is the probability to conclude that there was no seeding effect when it really exists and $(1-\beta)$ is the power of the test, defining the probability of detecting a seeding effect when it really exists; $\sigma^{2}$ is the variance of the simple ratio (ratio of the seeded unit parameters to the non-seeded unit parameters) and $\delta=($ SR-1). As can be seen, the greater the variance and the smaller the seeding effect, the greater number of cases are needed to get a given statistical significance.

According to these calculations and estimating that the possible average increase in precipitation from an experimental unit would be roughly 40\%, 120 experimental units would be needed to obtain a statistical significance level of $5 \%$. This estimation is based in the results obtained in previous experiments using cloud systems as experimental units, as PCMAT in Camagüey and the Thailand and Texas experiments, which obtained increments greater than $65 \%$ for experimental units of $400-600 \mathrm{~km}^{2}$ and considering that the greater extent of the experimental unit in EXPAREX $\left(2000 \mathrm{~km}^{2}\right)$ implies probable dilution of the seeding effect. Considering that the experiment will be carried out for 3-4 months a year and that an average of 10 experimental units can be treated per month, 4 years of randomized experiment are projected (Pérez et al., 2005).

\subsection{Evaluation}

The evaluation procedure will focus both on cells and on experimental units containing them. The parameters to be evaluated include simple ratios for seeded (S) and not seeded (NS) cases of cloud top heights, reflectivity factor, precipitation echo area, lifetime and precipitation volume. Seeding effects must appear in most of the analysis and these have to be consistent with the conceptual model. Some of the results must be statistically significant, and particularly the precipitation enhancement ratio, between the averaged rainfall volume for the S sample and the NS sample. The use of ratios is based on the arguments of Gabriel (1999), who found that, for samples consisting of more than 100 experimental units, the ratio method is as precise as the more rigorous, but more complex re-randomization approach. Woodley and Silverman (2003) found that this holds even for smaller samples.

The requirement of physical plausibility will be tested by detailed documentation of case studies and specially designed 
measurements, as well as by analyzing the statistical behavior of the physical parameters of the experimental clouds.

\section{EQUIPMENT, MEASUREMENT SYSTEMS AND DATA PROCESSING PROCEDURES.}

\subsection{Radar}

For the control and track of cloud cells and precipitation, automated MRL-5 radar is used. The characteristics of the radar are the following: wavelength: $10.15 \mathrm{~cm}$ (S band); and peak power $510 \mathrm{~kW}$; minimum detectable signal $-136 \mathrm{~dB} / \mathrm{W}$; frequency; pulse duration $2.0 \mu \mathrm{s}$; beam width $1.5^{\circ}$. With the radar and aircraft information, it is possible to follow the time evolution of cloud characteristics according to their development stage. The radar is located at $77^{\circ} 50^{\prime} 42^{\prime \prime} \mathrm{W}$ and $21^{\circ} 23^{\prime} 03^{\prime \prime} \mathrm{N}$, on a hill at $4 \mathrm{~km}$ to the south-south west of the Camagüey airport. The radar software system (Pozas et al., 2007) provides digital information about the evolution of clouds and precipitation inside a radius of $300 \mathrm{~km}$, in the form of digital maps of the cloud tops, reflectivity or rainfall intensity constant altitude plan position indicator (CAPPI) for different layers and layer width, maximum reflectivity, maximum reflectivity altitude, and range height indicator (RHI).

Grid size for the calculation of radar information can be changed from $0.1 \times 0.1 \mathrm{~km}$ to $10 \times 10 \mathrm{~km}$ with $0.1 \mathrm{~km}$ step. Radar information is available in the Experimental Coordination Center PCs in the form of multiple simultaneous indicators. An example of the operational radar output can be seen in Figure 3 for October 10, 2006, at 15:22 LDT. In addition to the radar indicators, the radar software can show the aircraft tack and the current aircraft position, and also the $25 \mathrm{~km}$ circumference limiting the floating target, calculated by an objective technique.

\subsection{Methodology of radar cloud and precipitation observations}

For radar observations, the following methodology was applied (Gamboa-Romero et al., 2005):

- The radar operator executes an hourly volume scan using an angular velocity of 4 turns per minute for 16 antenna turns with elevation angle growing from $1.5^{\circ}$ to $21.3^{\circ}$.

- If no echo is found within $150 \mathrm{~km}$ of the radar, but forecast indicates convective development, then after 09:00 LDT, operator changes the observation regime to every half an hour scans.

- If a radar echo is detected over the Island or less than $15 \mathrm{~km}$ offshore, the observation regime is changed to a scan every 15 minutes.

- When a radar echo is found over the Island inside a radius of $150 \mathrm{~km}$, the period of scanning is turned to 5-6 min.

One of the main tasks of a floating target cloud seeding experiment is to determine the speed and direction of the target. The radar information about the displacement vector of the floating target is used for the selection of the experimental cloud systems and delimitation of the experimental units during the flight and also to calculate the intensity and volume of the precipitation in the target in the evaluation process.

The floating target tracking algorithm (Novo et al., 2007) is based on the following hypothesis: the experimental unit will follow the average movement of the surrounding storms. For each maximum reflectivity radar image, the method identifies as storms all the groups of pixels with reflectivity and area values greater than certain thresholds. The reflectivity threshold

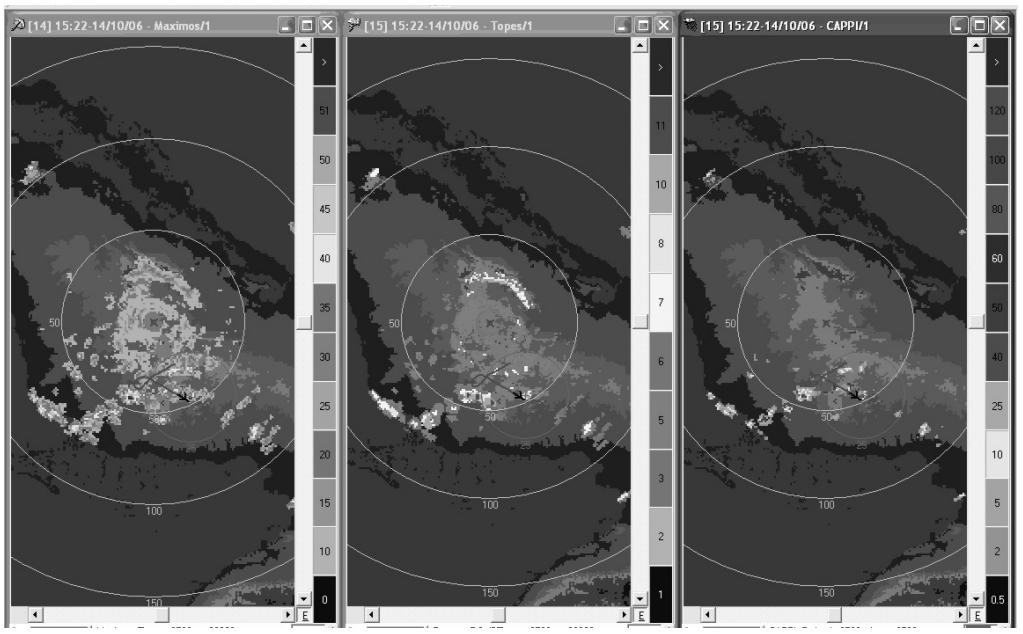

Figure 3 - Operational radar display showing simultaneous distributions of maximum radar reflectivity (left window), cloud top height (central window), and precipitation intensity (right window)., for October 10, at 15: 22 LDT. In the radar indicators can be seen the instrumented aircraft track and the $25 \mathrm{~km}$ radius boundary of the floating target. 
value (25 dBZ) is applied first, and consequently, connected components (up to second nearest neighbors) are labeled. Afterwards, the area threshold $\left(7 \mathrm{~km}^{2}\right)$ is applied to discard the smaller echoes. Then, every echo region (storm) is associated with an ellipse, the normalized second order moments of which are equal to the ones of the echo region. This constraint leads to an eigenvalue problem allowing obtaining the parameters of the ellipse.

At the treatment instant, which is taken as initial time for tracking, all present storms are identified, and the corresponding ellipses are defined by the algorithm. The circumference defining the experimental unit boundary is displayed, centered at the treatment point and extending to a radius of $25 \mathrm{~km}$. In the next scan, every storm in the radar's field of vision is tracked by choosing the new center positions that are located at the minimum distances from the centers in the previous scan, provided a certain limit distance is not attained (typically $5 \mathrm{~km}$ for a time lag of $5 \mathrm{~min}$ between scans). After all the storms have been identified in the new step, their displacement vectors are obtained. An average displacement vector of the storms contained inside a radius of up to 100 $\mathrm{km}$ neighborhood of the treated cloud is then calculated. This average displacement vector is assigned to the experimental unit. As output of the processing program, an image with the last maximum reflectivity map and the subsequent positions of the superimposed experimental unit circle is obtained, and also a text file including date, time, coordinates of the center and the main parameters of the seeding circle for every instant, as well as for the total tracking time. The algorithm stops to follow an experimental unit when the elapsed time with maximum rainfall rate less than $2 \mathrm{~mm} / \mathrm{h}$ inside the seeding circle reaches $30 \mathrm{~min}$. As an example, Figure 4 shows the trajectory of the first experimental unit obtained on October 3, 2006 for 1, 2 and $3 \mathrm{~h}$ of tracking, until it was almost dissipated. This area moved fast $(27 \mathrm{~km} / \mathrm{h}$ in average) and maintained a course near to WSW.

Rainfall rates "I" are estimated from radar reflectivity "Z" using a empirical standard Z-I relationship between these magnitudes, but the great variability of raindrop size distributions in different types of clouds and for different meteorological situations (Martínez and Gori, 1999) causes that this relationship is far for being the same for different days and even for different regions of the experimental areas on the same day, which is a significant source of error in rainfall rate and rainfall volume estimation by radar. To reduce this error, the estimation of rainfall rates and volumes from the radar is calibrated every day by the rain gauge network of the area, including four micro-networks of continuously recording digital raingauges (Gamboa el al., 2005).

\subsection{Equipment of the instrumented An-26 aircraft}

\subsection{1: Instrumented aircraft}

An instrumented An-26 aircraft was used as a measuring and cloud seeding platform. The aircraft was hired from the Cuban Aero Gaviota Company and was adapted in a reversible way so as to be instrumented only for the experimental period. Figure 5 shows the instrumented aircraft. The external sensors are installed in the right and upper hatches of the pilots' cabin. The support of the flair launching system can be seen in the central-right side of the aircraft. The general sketch of the instruments in the aircraft is shown in Figure 6.

\subsubsection{Measuring and computing complex}

The measuring and computing complex (MCC) (Figure 7) is distributed in two stands, located in the left part of the cargo cabin of the aircraft, including a data collection, processing and archiving system, complex DAS-VG-001 including air speed meter, altimeter and thermometer, braking temperature sensor P-104, Large particle spectrometer LPS, positioning system GPS III plus, Nevzorov's liquid and total water content (LWC/ TWC) hot wire probe IVO, aircraft condensation hygrometer $\mathrm{ACH}$ and thermodynamic fluctuation complex (TFC). The

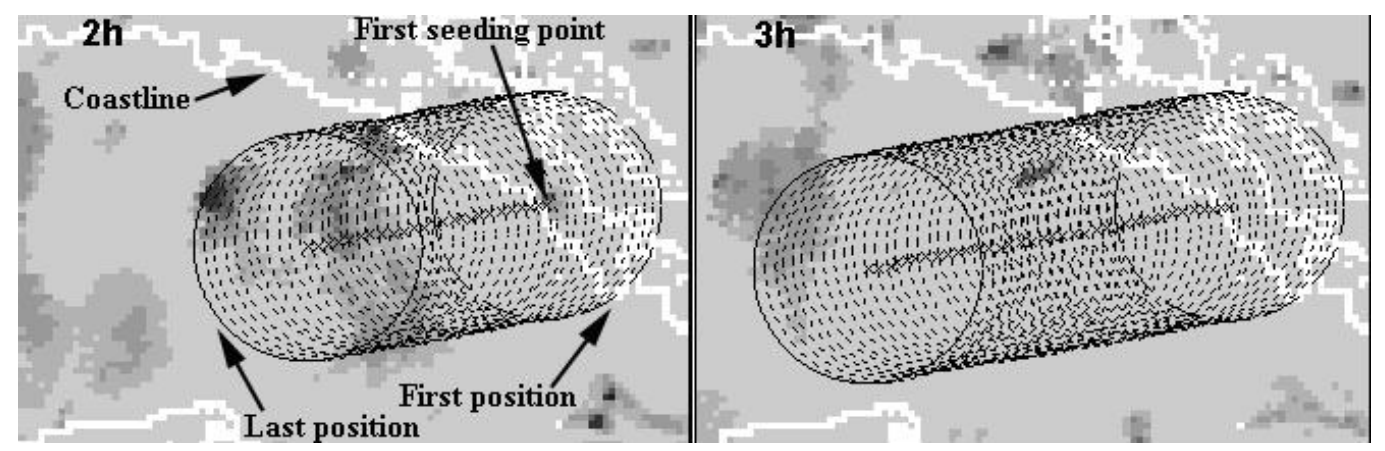

Figure 4 - Sequence of circumferences, forming the track of an experimental unit treated in October 3, 2006. The contours refer to the radar image corresponding to the last position. Left: two hours track. Right: Three hours track. 


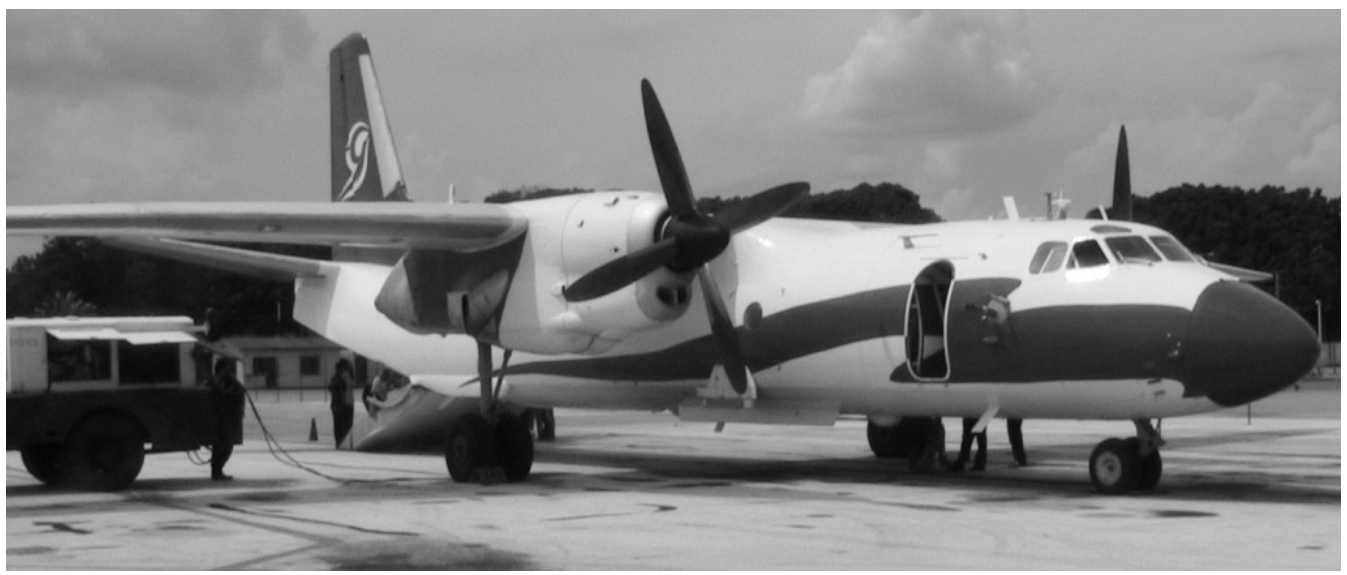

Figure 5 - Instrumented An-26 aircraft used in EXPAREX.

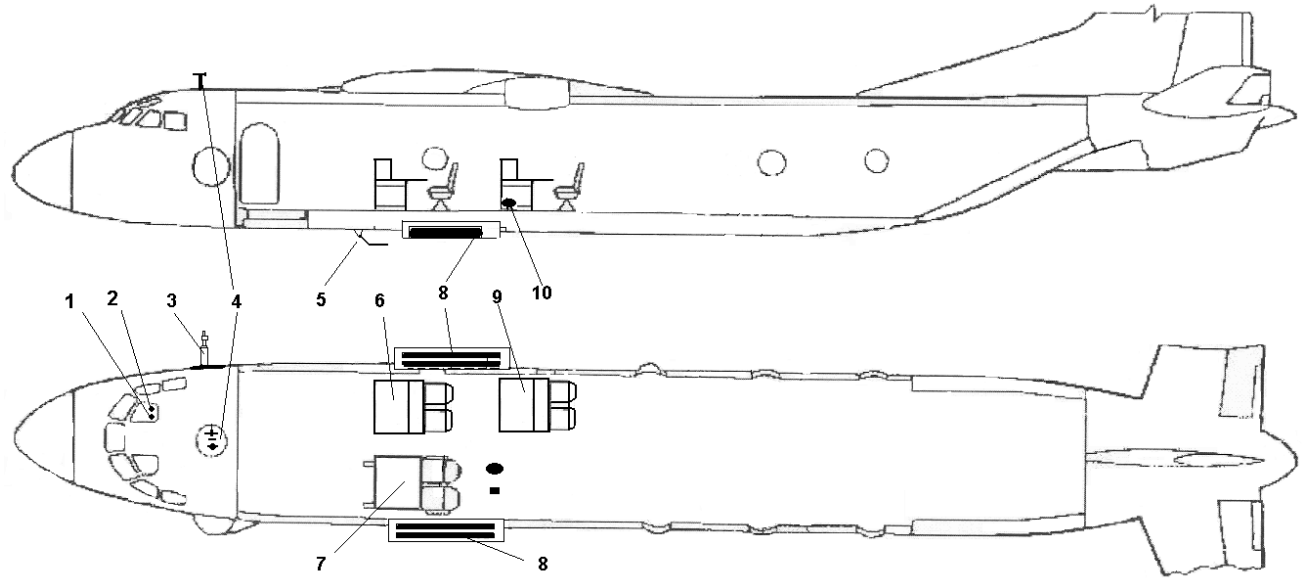

Figure 6 - Component sketch of the instrumented An-26 aircraft. 1 -2. Antennae of the GPS receivers of the complex of measurement and computing complex (MCC) and the flight control system. 3. Sensor of the liquid water content (LWC) probe IVO and of the large particle spectrometer (LPS). 4. Sensors of the thermodynamic fluctuation complex and the condensation hygrometer. 5. On-board antenna of the flight control system. 6 . First stand of MCC (thermodynamics complex) . 7. Launching flare system control stand 8. Beams of the flare launching system ASO-2I. 9. Second stand of MCC (turbulence complex) 10. Gyroscopes and aircraft load sensors of the turbulence complex.

control system performs data collection from with a frequency of $20 \mathrm{~s}^{-1}$. A description follows of the functioning principle of the main measuring instruments.

\section{a. Large particle spectrometer}

Nevzorov's large particle spectrometer (LPS) is an optical probe, (Mazin and Shmeter, 1977; Nevzorov, 1996) intended for measuring particles in a range of diameters from 0.2 to more than $6 \mathrm{~mm}$. It has 12 channels, whose resolution decreases with diameter. Its working principle may be summarized as follows. A collimated light beam passes through two narrow slits $(0.12 \mathrm{~mm}$ wide) and is focused on a photodetector. The cloudy air crosses the beam axis, forming a sample volume of $25 \mathrm{~mm} \times 28 \mathrm{~mm} \times 0.12$ $\mathrm{mm}$. Every time that a particle intersects the measuring volume, the light flow on the photodetector decreases proportionally to the area covered by the particle, which is also nearly proportional to the particle size for the range of measurement, as the minimum diameter is nearly twice the slit width. This causes a response pulse that is subsequently amplified and sent to a 12 channel integral pulse amplitude analyzer. The output signal for each channel is the frequency of passing particles by the measuring volume, from which the number and concentration of particles of a given size range, is obtained. The averaging time for the particle concentration is less than $0.5 \mathrm{~s}$.

\section{b. Solid and liquid water hot wire probe}

Liquid water content from cloud droplets was measured with Nevzorov's hot wire probe (IVO), with sensitivity from 0.003 to $0.01 \mathrm{~g} \mathrm{~m}^{-3}$, depending on flight conditions, and measuring range up to $3 \mathrm{~g} \mathrm{~m}^{-3}$. The two sensors allow obtaining total (liquid + solid) water and only liquid water in separate outputs, so that ice content can be obtained from a 

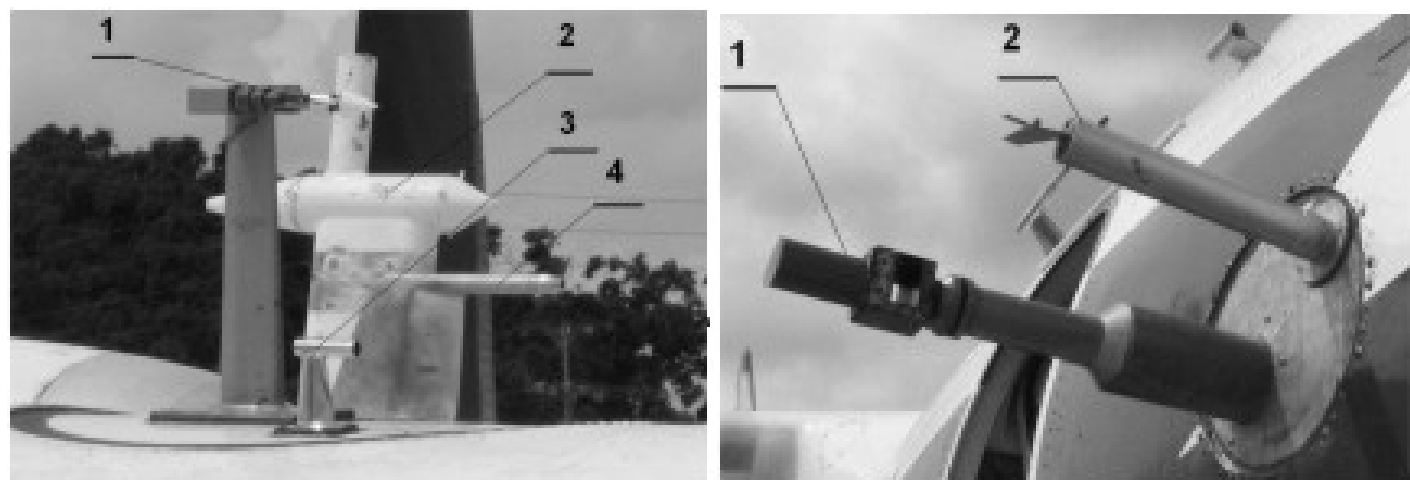

Figure 7 - MCC sensors, installed in the upper hatch of the pilot's cabin Right: Thermodynamic complex: 1 - High frequency temperature sensor; 2 - Sensor of the condensation hygrometer (ACH); 3 - Temperature sensor P-104; 4 - Pitot static tube PPD-1. Left: Cloud and precipitation water sensors.

simple calculation. The measuring area of both sensors is 0,5 $\pm 0,1 \mathrm{~cm}^{2}$, differing only in geometrical form. The error of the measurements is less than $10 \%$. Work principles and general characteristics of this instrument can be found in Mazin and Shmeter, (1977) and Nevzorov, (1996). Inter-comparisons between Nevzorov's hot wire probe and the well-known PMS King probe have shown close agreement (Korolev et al., 1996).

\section{c. Condensation hygrometer}

The condensation hygrometer is designed to measure the water vapor content of the air from aircraft in the form of dew point or frost point temperature with an error of less than $0.5^{\circ} \mathrm{C}$. It is based on the maintenance of the phase equilibrium between the condensate on a cooled mirror sensor (Mezrin M.Yu., E.V. Starokoltsev, 2001) and the water vapor in the air.

\section{d. Thermodynamic fluctuation complex}

The thermodynamic fluctuation complex (TFC) is designed to measure and register the static and dynamic pressures, air temperature, attack angle, aircraft vertical acceleration in the aircraft center of gravity (aircraft load), as primary output. These measurements are digitally processed to obtain the fluctuations of longitudinal and vertical wind velocities, real aircraft speed relative to the air and real air temperature. From these parameters, spectral densities and other turbulent parameters are calculated (Strunin M.A. and Hiyama T., 2005). Previously filtered fluctuation data of $\boldsymbol{w}^{\prime}, \boldsymbol{u}^{\prime}, \boldsymbol{T}^{\prime}$ and LWC were processed using the Morlet wavelet transform (Grossman and Morlet, 1984).

\subsubsection{Flare launching system}

Four ASO-2I flare launching systems (Figure 8) are installed in the aircraft to deliver the AgI aerosol into the seeded clouds. Each launcher, carrying two 32 flare cassettes (Figure 9a), was attached to a bomb carrier at both sides of the aircraft (In 2005 and 2006, only two units were installed, and in 2007, two additional units were added). The amount of flares to be launched at one shot and the interval between shots were controlled by the seeding operator from his stand in the aircraft passenger cabin (Figure 9b).
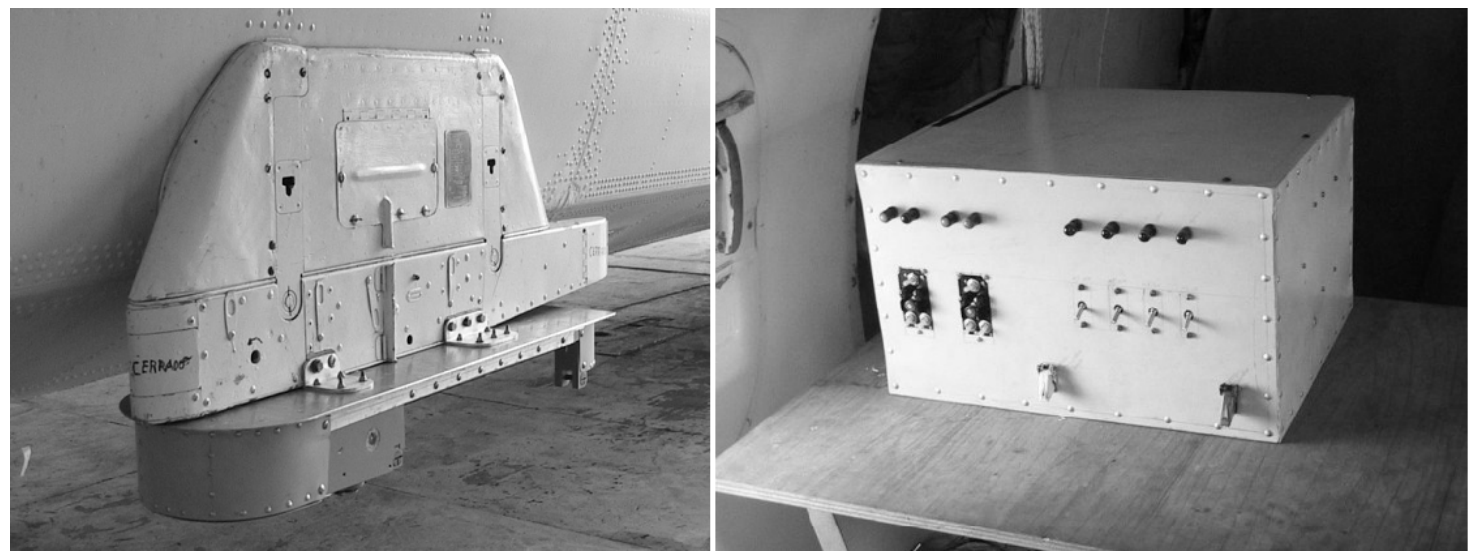

Figure 8 - Flare launching system ASO-2I, installed at the aircraft bomb carrier (a). Launcher control unit (b). 
A data transmission system "Land - Aircraft -Land" allows to display the locations and flight trajectory of aircrafts in real time on a display in the Operative Center, as well as to send aboard the aircraft radar maps of cloud and precipitation distribution in the area (Petrov, et al., 2007).

\section{MAIN PHYSICAL CHARACTERISTICS OF THE EXPERIMENTAL CLOUDS}

\subsection{Liquid water content}

One of the most important seedability criteria for glaciogenic seeding of convective clouds is the presence of abundant supercooled water at the seeding level. Figure 9 shows the histograms of the average (left) and maximal (right) IVO liquid water content in experimental clouds of 2006-2007 compared with the similar quantities for the measurements made in similar clouds in the period 1987-1990 (Pérez et al., 2008) .
Both the form of the frequency distribution and the values of LWC measured in both periods are approximately coincident. The average and maximal LWC values at flight level were 0.49 and $1.12 \mathrm{~g} / \mathrm{m}^{3}$ in $2006-2007$ and 0.50 and 1.03 $\mathrm{g} / \mathrm{m}^{3}$ in $1987-1990$.

\subsection{Vertical velocities}

Figure 10 shows frequency distributions for maximum values of upwards (right) and downwards (left) wind velocities in cloud belonging to the 20 experimental units treated in 20062007. The same distribution is shown for the experimental clouds treated in the period 1987-1990.

The distributions of maximum and minimum vertical velocities for both periods are roughly similar, which shows that both samples are comparable regarding vertical draft characteristics. Vertical velocity maxima were greater than $6 \mathrm{~m} / \mathrm{s}$ for $57 \%$ of the cases in 2006-2007 and for 56\% of the cases in 1987-1990. . This result, together with the similarity in LWC

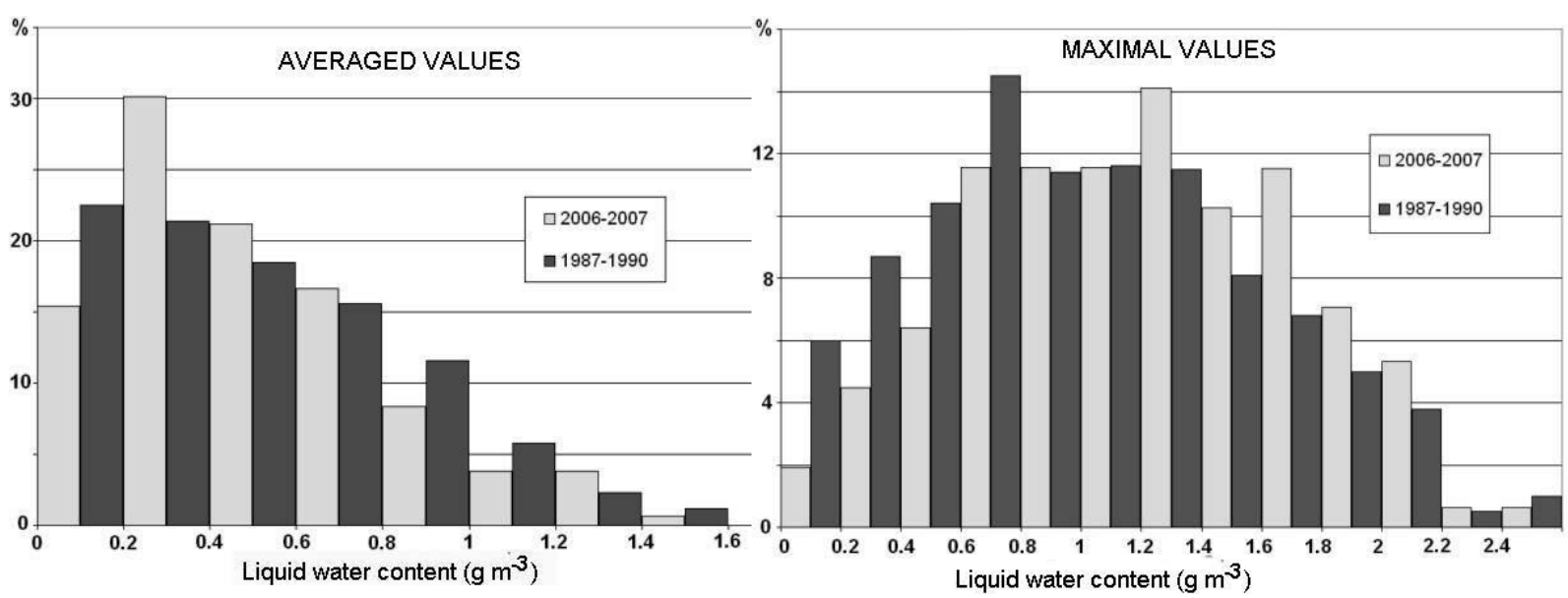

Figure 9. Flare launching system ASO-2I, installed at the aircraft bomb carrier (a). Launcher control unit (b). 9 - Frequency distributions of averaged (left) and maximum (right) liquid water content for the clouds belonging to experimental units treated in the periods 2006-2007 and 1987-1990.
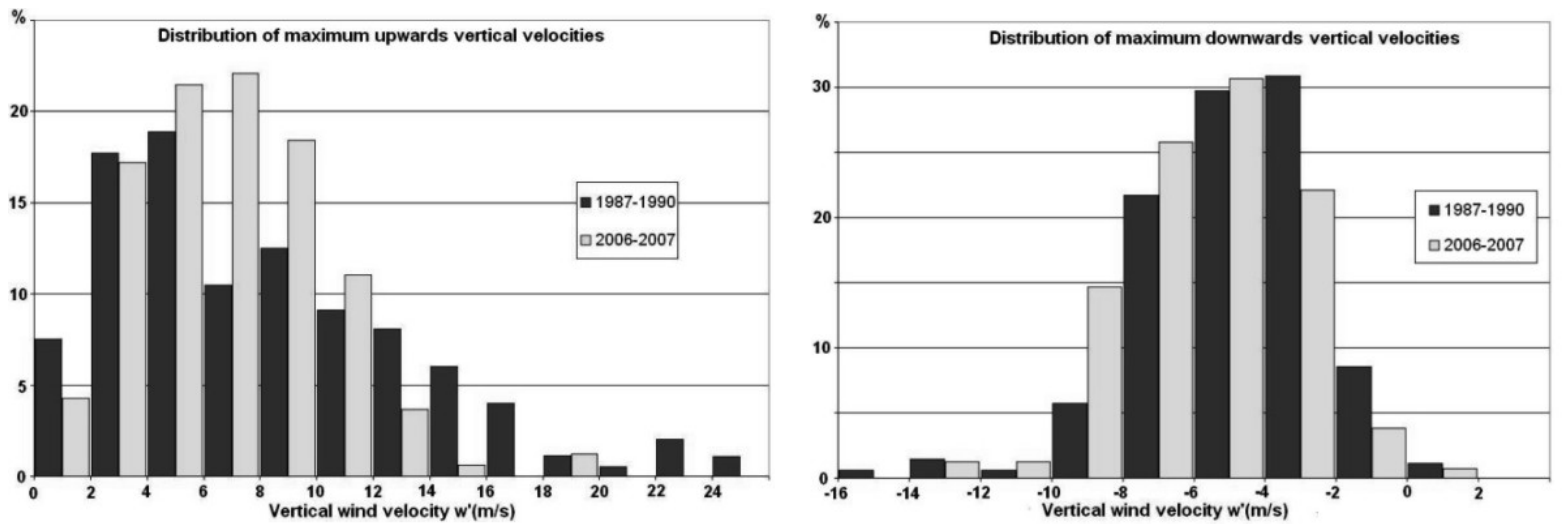

Figure 10 -Frequency distributions for maximum values of upwards (right) and downwards (left) wind velocities in cloud belonging to the experimental units treated in the periods 2006-2007 and 1987-1990. 
Table 1 - Experimental flights 2006-2007.

\begin{tabular}{|c|c|c|c|c|}
\hline Date & $\begin{array}{c}\text { Flight } \\
\text { number }\end{array}$ & $\begin{array}{c}\text { Number of } \\
\text { experimental } \\
\text { units }\end{array}$ & $\begin{array}{c}\text { Number of } \\
\text { measurement } \\
\text { intervals }\end{array}$ & $\begin{array}{c}\text { Number of } \\
\text { clouds }\end{array}$ \\
\hline $2006 / 10 / 03$ & 2 & 1 & 5 & 5 \\
\hline $2006 / 10 / 06$ & 4 & 2 & 6 & 6 \\
\hline $2006 / 10 / 10$ & 6 & 3 y 4 & 12 & 12 \\
\hline $2006 / 10 / 11$ & 7 & 5 & 17 & 16 \\
\hline $2006 / 10 / 12$ & 8 & 6 & 11 & 7 \\
\hline $2006 / 10 / 14$ & 9 & 7 & 13 & 11 \\
\hline $2007 / 08 / 24$ & 3 & 8 & 8 & 12 \\
\hline $2007 / 08 / 27$ & 4 & 9 & 10 & 18 \\
\hline $2007 / 08 / 30$ & 5 & 10 & 4 & 8 \\
\hline $2007 / 08 / 31$ & 6 & 11 & 8 & 10 \\
\hline $2007 / 09 / 10$ & 7 & 12 & 8 & 11 \\
\hline $2007 / 09 / 11$ & 8 & 13 & 11 & 18 \\
\hline $2007 / 09 / 15$ & 10 & 14 & 6 & 10 \\
\hline $2007 / 09 / 17$ & 11 & 15 & 13 & 14 \\
\hline $2007 / 09 / 18$ & 12 & 16 & 8 & 14 \\
\hline $2007 / 09 / 22$ & 13 & 17 & 9 & 223 \\
\hline $2007 / 09 / 27$ & 14 & 18 & 11 & \\
\hline $2007 / 09 / 28$ & 15 & 19 & 8 & \\
\hline $2007 / 10 / 04$ & 16 & 20 & 4 & 198 \\
\hline Totals & & 20 & & \\
\hline
\end{tabular}

Table 2 - Radar measured parameters of the experimental units of 2006 and 2007.

\begin{tabular}{|c|c|c|c|c|}
\hline$\#$ & Date/time & $\boldsymbol{\Delta t}(\mathbf{m i n})$ & $\mathbf{V}(\mathbf{k m} / \mathbf{h})$ & $\mathbf{Q}(\mathbf{k T})$ \\
\hline 1 & $031006-14: 20$ & 240 & 27 & 55273 \\
\hline 2 & $061006-15: 20$ & 400 & 11 & 12841 \\
\hline 3 & $101006-13: 50$ & 60 & 12 & 16 \\
\hline 4 & $101006-14: 50$ & 290 & 10 & 1141 \\
\hline 5 & $111006-14: 50$ & 350 & 11 & 1450 \\
\hline 6 & $121006-14: 45$ & 115 & 15 & 35 \\
\hline 7 & $141006-15: 15$ & 525 & 18 & 25391 \\
\hline 8 & $240807-14: 05$ & 550 & 19 & 9388 \\
\hline 9 & $270807-13: 35$ & 300 & 22 & 12133 \\
\hline 10 & $300807-14: 00$ & 275 & 8 & 5535 \\
\hline 11 & $310807-13: 15$ & 290 & 7 & 1453 \\
\hline 12 & $100907-14: 05$ & 540 & 25 & 4868 \\
\hline 13 & $110907-13: 30$ & 520 & 17 & 24378 \\
\hline 14 & $150907-13: 40$ & 705 & 16 & 6704 \\
\hline 15 & $170907-14: 15$ & 540 & 7 & 13014 \\
\hline 16 & $180907-14: 30$ & 615 & 5 & 4241 \\
\hline 17 & $220907-13: 55$ & 230 & 14 & 1029 \\
\hline 18 & $270907-13: 15$ & 655 & 7 & 14473 \\
\hline 19 & $280907-13: 45$ & 355 & 11 & 4975 \\
\hline 20 & $041007-13: 25$ & 595 & 5 & 11158 \\
\hline
\end{tabular}

distributions shows that the two samples contain similar types of clouds at the time of penetration, and so, it corroborates that the same cloud selection criteria have been applied in both periods.

\section{PRELIMINARY INFORMATION ABOUT EXPERIMENTAL UNITS}

Table 1 lists the experimental flights including the 20 experimental units documented in the 2006 and 2007 experiments, including date, and the amount of clouds and intervals measured by aircraft equipment included in each unit.

The parameters of the radar echoes of the experimental units were obtained for each radar scan and integrated all over the lifetime of the unit for the eventual evaluation of the seeding effect. Table 2 shows their lifetime $\Delta \mathrm{t}$, in minutes, average displacement speeds, in $\mathrm{km} / \mathrm{h}$ and the total water mass corresponding to each experimental unit in kt (kilotons).

As shown in Table 2, experimental units have lifetimes from 1 hour to more than 11 hours and total rainfall masses from 16 to ore than $55000 \mathrm{kt}$. This evidences a much dispersed character of the main evaluation parameters. Up to the present, the kind of treatment (seeded or not seeded) of each experimental unit has not been unveiled, and it will remain unknown until at least more of a half of the expected experimental units have been made.

\section{SUMMARY AND CONCLUSIONS.}

A general overview of the Randomized Convective Cold Cloud Seeding Experiment in Extended Areas has been given, including experimental design, observation and flight methodologies, description of the measuring equipment, physical characterization of measured clouds and the radar measured integral parameters of the first 20 experimental units. The experimental design grants the randomized and unbiased collection of experimental units on a blind base which is documented before unveiling the character of the treatment. As a result of the analysis, it can be concluded that the clouds in the preliminary sample of 20 experimental units comply with 
suitable physical characteristics for experimental clouds under the dynamic seeding hypothesis. It is expected that the total amount of experimental units needed for the evaluation of the experiment will be completed in three more 4 month seasons which should take place in the summer seasons of 2010, 2011 and 2012.

\section{REFERENCES}

BARNSTON, A.; FLUECK, J.A.; BIONDINI, R.. The Florida Area Cumulus Experiment second phase (FACE II). Part. II: Replicate and Confirmatory Analysis. J. Climate Appl. Meteor., v. 22, p. 1529 - 1540. 1983.

COTTON, W. R. Numerical simulation of the precipitation development in supercooled cumuli. Part. I. Mon. Wea. Rev., v. 100, p. 757-763. 1972a.

COTTON, W. R. Numerical simulation of the precipitation development in supercooled cumuli. Part. II. Mon. Wea. Rev., v. 100, p. 763-784. 1972b.

GABRIEL, K. R. Ratio statistics for randomized experiment in precipitation stimulation. J. Appl: Meteor. v. 38. p. 290-301. 1999.

GAGIN, A.; NEWMAN. J. The second Israeli randomized cloud seeding experiment: Evaluation of results, J. Appl. Meteor., v. 20, p. 1301 - 1311. 1981.

GAMBOA MOREIRA, A.; GAMBOA ROMERO, F.; NOVO, $\mathrm{S}$. Determinación cuantitativa de las precipitaciones por radar ajustada según la información pluviométrica. Memorias del III Congreso Cubano de Meteorología. 5 al 9 de diciembre del 2005. La Habana, Cuba., ISBN p. 959-7160-31-5. 2005.

GAMBOA ROMERO F.; PÉREZ, C. A..; MARTÍNEZ D. ; GAMBOA MOREIRA A. El radar meteorológico camagüeyano como una herramienta para la coordinación científica de vuelo y evaluación de los experimentos de incremento artificial de las precipitaciones. Memorias del III Congreso Cubano de Meteorología. 5 al 9 de diciembre del 2005. La Habana, Cuba. Publicación electrónica en CD, ISBN p. 959-7160-31-5. 2005.

GROSSMANN A.; MORLET J. Decomposition of Hardy Functions into Square Integrate Wavelets of Constant Shape, SIAM J. Math. Anal., v. 15, p. 723 - 736. 1984.

KOLOSKOV B.; ZIMIN B.; BELIAEV V.; SEREGIN Y.; CHERNIKO, V.; PETROV, V.; VALDÉS M; MARTÍNEZ D.; PÉREZ C.A.; PUENTE G. Results of Experiments on Convective Precipitation Enhancement in the Camagüey Experimental Area. Cuba. Jour. Appl. Meteor., v. 35, n. 9 , p. 1524-1534. 1996.

KOROLEV A. V.; STRAPP W. J.; NEVZOROV A. N. On the accuracy of Nevzorov airborne hot wire LWC/TWC probe., 12th International Conference on Clouds and Precipitation. . Zürich, Switzerland, Aug. 19-23, 1996. Proceedings. v. 1, p. 346-349. 1996.

LEVIN Z. On the state of cloud seeding for rain enhancement. Report. The Cyprus Institute. http://eewrc.cyi.ac.cy/ system/files/Report_EEWRC_omformat_0.pdf. 2009.

MARTÍNEZ D. Turbulence Parameters and Vertical Drafts in Cuban Convective Clouds. Rev Bras. Meteor., 14(2). 1999. MARTÍNEZ D.; GORI E. G., Raindrop size distributions in convective clouds over Cuba. Atmospheric Research., v. 52, p. 221-239. 1999.

MARTÍNEZ D.; RIVERO I; BÁEZ R. Caracterización estadística de los perfiles meteorológicos de Camagüey en horas de la tarde y su relación con la lluvia . Rev. Cub. Meteor, v. 9, n. 1. 2002.

MAZIN I. P.; SHMETER S. M. (EDS). Cumulus clouds and the deformation of the fields of meteorological elements related with them (In Russian). Trudy TsAO, v. 134, 280 p. 1977.

MEZRIN M.Y.; STAROKOLTSEV E.V. Aircraft Condensation Hygrometer and some results of measuring humidity in the zone of the equatorial tropopause. Atmospheric Research, v. 59-60, p. 331-341. 2001.

NEVZOROV A. N. CAO aircraft instrumentation for cloud physics. 12th International Conference on Clouds and Precipitation. . Zürich, Switzerland, Aug. 19-23, 1996. Proceedings. v. 1., p. 371-374. 1996.

NOVO S.; MARTÍNEZ D.; PÉREZ C. A.; KOLOSKOV B.;GAMBOA F. Radar tracking method for cloud seeding experimental units over Cuba. Ninth WMO Scientific Conference on Weather Modification (Antalya, Turkey, 22-24 October 2007). WMP No. 44. WMO TD. No. 1406. 2007.

PÉREZ C. A.; MARTÍNEZ D.; PETROV, V. Microstructure, mixing and turbulence in cumulus clouds over Cuba and the Caribbean Sea. Proceedings of the WMO Workshop on Cloud Microphysics and Applications to Global Change, WMO/TD 537, Toronto, Canada, p. 254 - 256. 1992.

PÉREZ C. A.; D. MARTÍNEZ; F. GAMBOA; V. PETROV; B. KOLOSKOV; B. DANIELYAN. Diseño del experimento cubano para el incremento artificial de la lluvia en áreas extensas. Memorias del III Congreso Cubano de Meteorología. 5 al 9 de diciembre del 2005. La Habana, Cuba. Publicación electrónica en CD, ISBN 959-7160-31-5. 2005.

PÉREZ C. A.; MARTÍNEZ, D.; PETROV, V.; POMARES, I.; KOLOSKOV, B.; GAMBOA ROMERO, F. An exploratory analysis of the potential for rainfall enhancement in the randomized convective cold cloud seeding experiment in extended areas in Cuba (EXPAREX). Proceedings of the 15th International Conference on Clouds and Precipitation. Cancun, July 7-11, 2008. 
PÉREZ, C.; OMS M.; MARTÍNEZ D.; PETROV V. Phase Composition and Seedability of Cumulus Clouds in the Camagüey Meteorological Site. Sixth WMO Scientific Conference on Weather Modification, Pasteum. WMP Report No. 22 WMO/Td No. 596, 2, pp.379-382. 1994.

PETROV V..; MARTÍNEZ D.; PÉREZ C. A. The microphysical and thermodynamic characteristics of tropical convective clouds by results of measurements on Cuba. Proceedings of the 13th International Conference on Clouds and Precipitation. Bologna, Italy. 2004.

PETROV V.; EGOROV O.; MELNIK S.; ZAKHAROV A; SKURATOV S.: Data transmission system "land - aircraft -land". Ninth WMO Scientific Conference on Weather Modification (Antalya, Turkey, 22-24 October 2007). WMP No. 44. WMO TD. No. 1406. 2007.

POZAS, W. (2007). Software Vesta-Proceso versión 5.3.13.0. Informe del Laboratorio de Desarrollo Técnico, Centro Meteorológico de Camagüey.

ROGERS, R.R.; YAU, M.K. A short course in cloud physics. 3rd edition. Pergamon Press. 292 pp. 1989.

ROSENFELD, D.; SUDHICOSES, P.; SUKANJANASET, W.; RUANGSUTTINARUPARP, S.; KHANTIYANAN W. The Thailand cold - cloud seeding experiment: Results of statistical evaluation. Preprints 7th WMO Scinetific Conference on Weather Modification, Chian Mai, Thailand, p. $25-28.1999$.

ROSENFELD, D.; WOODLEY, W. L. Effects of cloud seeding in west Texas: Additional results and new insights. J. Appl. Meteor., v. 32, p. 1848-1866. 1993.
SILVERMAN, B.A. Static mode seeding of summer cumuli. A review. In: R. R. Braham (Editor), Precipitation Enhancement. A Scientific Challenge. Meteorological Monograph No. 43. American Meteorological Society, p. 7-24. 1986.

SIMPSON J.; BRIER G. W.; SIMPSON R. H. Stormfury cumulus seeding experiment 1965: Statistical analysis and main results. J. Atmos. Sci., v. 24, p. 508-521. 1967.

STRUNIN M.A.; HIYAMA T. Spectral structure of smallscale turbulent and mesoscale fluxes in the atmospheric boundary layer over a thermally inhomogeneous land surface, Boundary-Layer Meteorol., v. 117, p. 479 - 510. 2005

WORLD METEOROLOGICAL ORGANIZATION. WMO

Statement on Weather Modification. http://www.wmo.int/ pages/prog/arep/wwrp/new/documents/WMR documents. Final 27_April_1. FINAL.pdf, 2010

WOODLEY, W. L.; SAX, R. I. The Florida Area Cumulus Experiment: Rationale. Design, Procedure, Results, and Future Course. NOAA Technical Report ERL 354-WMPO 6. Boulder, Colo. 204 pp. 1976

WOODLEY, W.L.; JORDAN, J.;. SIMPSON, J.; BIONDINI R.; FLUECK, J.A.; BARNSTON A. Rainfall results of the Florida Area Cumulus Experiment, 1970 - 1976. J. Appl. Meteor., v. 21, p. 139 - 164. 1982

WOODLEY, W. L.; SILVERMAN B. A. Results of on-top glaciogénic cloud seeding in Thailand. Part. II: Exploratory Analyses. J. Appl. Meteor., v. 42, p. 939-951. 2003. 